\title{
Progress in energy efficiency standards of residential buildings in China's severe cold and cold zones
}

\author{
Zhenyu $\mathrm{Yu}^{1,2, *}$, Wei $\mathrm{Xu}^{1}$, Xi Chen ${ }^{1, *}$, Deyu $\mathrm{Sun}^{1}$, Jing Zhang ${ }^{1}$, Fei $\mathrm{Lu}^{1,2}$ and Changping Liu ${ }^{1}$ \\ ${ }^{1}$ China Academy of Building Research, Institute of Building Energy and Environment, 100013 Beijing North 3rd ring \\ east road 30, China \\ ${ }^{2}$ Tsinghua University, Building Science and Technology Department, 100084, China
}

\begin{abstract}
Since Chinese government released the first residential building energy efficiency standard in 1986, the energy efficiency of residential buildings have been improved significantly. Three editions of residential building energy efficiency standards in severe cold and cold zones have been issued in the past 30 years, meanwhile, a new version is in the course of development and will be released in 2018 . The paper reviews energy efficiency standards that have been issued for residential buildings in severe cold and cold zones in China, and development of new energy efficiency standards. The paper also describes the variation of key requirement in standards. Finally, future prospects for further developing energy efficiency standards for residential buildings in China are addressed. The findings show that the energy consumption reduction percentage has raised from $30 \%$ of JGJ $26-86$ to $65 \%$ of the JGJ $26-2010$. The insulation performance of roofs and external walls increased respectively by $103 \%$ and $83 \%$, and the window performance increased by $130 \%$.
\end{abstract}

\section{Background}

For purposes of coping with the climate change and energy saving, building energy efficiency has developed rapidly in the past 50 years. The standard is an important tool to promote building energy efficiency. Building energy efficiency standards and regulations are policy measures widely used to control energy consumption in buildings. It can help overcome some of the significant market barriers and ensure that cost-effective energy efficiency opportunities are incorporated into new buildings. This is especially important in developing countries where the number of new buildings is growing rapidly and the energy prices and market often do not encourage the use of efficient technologies. Research by Nadel [1] (1997) showed that trends towards increased use of efficiency standards are likely to continue, along with periodic updates to standards and growth in programs that complement them.

There are almost 1.5 billion $\mathrm{m}^{2}$ buildings built each year in China over the past 20 years, and nearly $70 \%$ are residential buildings. Residential buildings have a big energy saving potential. As one of the world's most rapidly developing economies, energy safety and environmental protection are urgent in China. As China government is likely to maintain rapid economic growth rates, the strategy for providing energy services and ensuring efficient use of energy is very important for China. So the government pay more attention to building energy efficiency with the development of economy.
Development of building energy efficiency standards has been an important issue in China. As energy consumption in buildings accounts for a significant portion of total societal energy requirements and is growing very fast, the potential for energy saving in the building sector is tremendous. The China building energy efficiency standardization work began with the tide of reform and opening-up in the 1980s. The overall developing trend of China building energy efficiency is to develop residential building energy efficiency first, then to develop nonresidential building, and first for the northern area then for the southern area. The JGJ26 "Design standard for energy efficiency of residential buildings in severe cold and cold zones" is very important in China building energy efficiency standard system. This paper briefly reviews energy efficiency standards that have been issued for residential buildings in severe and cold zones in China and development of new version of energy efficiency standards.

\section{The process of energy efficiency standards for residential buildings in China severe cold and cold zones}

The building heating energy in northern China is the major part of the total building energy consumption. Compared with the nonresidential building, the roadmap of building energy efficiency for residential was simple and clear in the 1980s. The JGJ26 "Design standard for energy efficiency of residential buildings in severe cold 
and cold zones" is the first building energy efficiency standard. Since then, building energy efficiency standards have been developed rapidly, 20 standards are published (see Table 1).

Table 1. China building energy efficiency standards in the past 30 years

\begin{tabular}{|c|c|c|c|}
\hline Number & $\begin{array}{c}\text { Publish } \\
\text { year }\end{array}$ & Name & $\begin{array}{c}\text { Serial } \\
\text { number }\end{array}$ \\
\hline 1 & 1986 & Thermal design code for civil building & JGJ24 \\
\hline 2 & 1986 & Energy conservation design standard for new heating residential buildings & JGJ26 \\
\hline 3 & 1990 & Energy conservation design standard for hotel buildings( provisional) & \\
\hline 4 & 1993 & Thermal design code for civil building & GB50176 \\
\hline 5 & 1993 & Standard of climatic regionalization for architecture & GB50178 \\
\hline 6 & 1993 & Energy conservation design standard for hotel buildings & GB50189 \\
\hline 7 & 1995 & Energy conservation design standard for new heating residential buildings & JGJ26 \\
\hline 8 & 2001 & $\begin{array}{l}\text { Design standard for energy efficiency of residential buildings in hot summer and cold winter } \\
\text { zone }\end{array}$ & JGJ134 \\
\hline 9 & 2003 & $\begin{array}{l}\text { Design standard for energy efficiency of residential buildings in hot summer and warm } \\
\text { winter zone }\end{array}$ & JGJ75 \\
\hline 10 & 2005 & Design standard for energy efficiency of public buildings & GB50189 \\
\hline 11 & 2007 & Code for acceptance of energy efficient building construction & GB50411 \\
\hline 12 & 2009 & Standard for energy efficiency test of residential buildings & $\mathrm{JGJ} / \mathrm{T} 132$ \\
\hline 13 & 2009 & Technical code for the retrofitting of public building on energy efficiency & $\mathrm{JGJ} / \mathrm{T} 176$ \\
\hline 14 & 2009 & Standard for energy efficiency test of public buildings & $\mathrm{JGJ} / \mathrm{T} 177$ \\
\hline 15 & 2010 & Design standard for energy efficiency of residential buildings in severe cold and cold zones & JGJ26 \\
\hline 16 & 2010 & $\begin{array}{l}\text { Design standard for energy efficiency of residential buildings in hot summer and cold winter } \\
\text { zone }\end{array}$ & JGJ134 \\
\hline 17 & 2012 & $\begin{array}{l}\text { Design standard for energy efficiency of residential buildings in hot summer and warm } \\
\text { winter zone }\end{array}$ & JGJ75 \\
\hline 18 & 2012 & Technical Specification for Energy Efficiency Renovation of Existing Residential buildings & $\mathrm{JGJ} / \mathrm{T} 129$ \\
\hline 19 & 2015 & Design standard for energy efficiency of public buildings & GB50189 \\
\hline 20 & 2016 & Thermal design code for civil building & GB50176 \\
\hline
\end{tabular}

So far, the JGJ26 "Design standard for energy efficiency of residential buildings in severe cold and cold zones" has been revised twice and 3 versions have been published. The process of this standard can be divided into three phases, which also represent the corresponding stages of the building energy efficiency standard system. They are initial stage (1980s-1990s), development stage (1995-2005) and mature stage (2005-now).

\subsection{Initial stage (1980s-1990s)}

From 1986, the first building energy efficiency design standards JGJ 26-1986 "Civil building energy efficiency design standards (residential building heating part)" (short for JGJ 26-86 or JGJ 26-1986) was issued and put into trial use till the revision completed in 1995, this period is the primary work of building energy efficiency Stage [2]. The energy saving rate goal of residential buildings in severe cold and cold areas is $30 \%$, which means that heating energy consumption of new residential buildings should reduce by $30 \%$ than the common residential buildings designed in 1980 . This is the minimum requirement of building energy efficiency. The main work to fulfill the goal is to promote the thermal performance requirement on building envelope.
JGJ 26-1986 is developed based on a large number of investigations and research, domestic and foreign experience. It has Chinese characteristics, such as the statistical method of heating degree days, the application of effective heat transfer coefficient method to estimate heating energy, the design method of heating system, the selection of the boiler, the determination of the pipeline minimum insulation thickness, the requirement of the water transmission coefficient. Compared with the foreign regulations or standards, the level of systematic and scientific is close, but limited to China's technical and economic level, there is a big gap in energy-saving technical measures and the thermal performance requirement of building envelope.

JGJ 26-1986 established the basic idea and methods of China's building energy efficiency design standards, it set a reference residential building designed from 1980 to 1981 (baseline). That means the reference residential building has the typical building structure and the typical energy efficiency of the heating equipment required by the standard to maintain reasonable indoor thermal environment parameters. The energy consumption of this building is a baseline of building energy efficiency standard when calculating the annual heating energy consumption and considered as $100 \%$. Actual building 
energy consumption are compared with the baseline and exports a relative energy saving rate.

\subsection{Development stage (1995-2005)}

In the initial stage, a lot of basic research work was finished, which provided a foundation for the update of standard. JGJ 26-95 is an upgraded version of JGJ 26-86, whose energy saving rate is $50 \%$ [3]. Compared with JGJ 26-86, the energy savings are $30 \%$.

The JGJ 26-95 standard not only improved the envelope thermal performance requirement, but also strengthened the HVAC system energy conservation requirements. Compared with the reference building, there has been a great improvement, but there is still a considerable gap compared with the relevant energysaving standards of the USA in the world. As an example, the rough concept is that the standard heat transfer coefficient of wall is 2.6 to 3.6 higher than that of the standards in the USA, the roof is 3.2 to 4.2 times higher, the $\mathrm{k}$-value of window is 1.4 to 2 times higher, and the air permeability is 3 to 6 times higher. In other words, the heating energy consumption of residential building designed with JGJ 26-95 is twice higher than the buildings in the USA at the same time [4].

\subsection{Mature stage (2005-now)}

JGJ 26-2010 was released in 2010, and renamed as "design standard for energy efficiency of residential buildings in severe cold and cold zones" [5]. The energy saving rate of JGJ $26-2010$ is $65 \%$. Compared with JGJ $26-95$, the energy savings are $30 \%$. The requirement of key energy saving measures are closed with developed country with the same climate. This version represented that the energy saving level of residential building energy efficiency standard is similar with that in the USA.

A new calculation method of heat loss index was introduced in JGJ 26-2010, that is an entire envelope thermal performance requirement method. This method gives more freedom for architect in design process. The requirement on line heat transfer coefficient of thermal bridge was also proposed in JGJ 26-2010. This standard made different requirements on shape coefficient and kvalues of building envelopes base on the different number of layers, this is much more easy to use.

\section{Development of key indices in energy efficiency standards}

The three versions of domestic energy efficiency standards mentioned above are compared in key indices to show the development of building performance. The domestic building energy efficiency standards usually include envelope, HVAC systems, pump design and so on, whereas the envelope and HVAC systems are the two most important aspects of energy efficiency standards. So these two aspects are compared. The contemporaneous
USA standards are also listed for reference [6]. Beijing is chosen as a typical city located in cold areas of China.

\subsection{Envelopes}

Building envelope is a building structure that surrounds the building heating and cooling zone, including building facades, floors, grounds, roofs, windows and doors, whose thermal performance has a great impact on the building energy consumption. The envelope elements contain roofs, external walls, floors, windows and so on. Their heat transfer coefficients are required in the standard.

In the 3 domestic standards, constraints of the same element may be ruled by different methods. For example, the maximum k-value of external wall in JGJ 26-86 is divided by the building shape coefficient, window type and direction, in JGJ 26-95 the direction is no longer thought about. While in more recent JGJ 26-2010, the floor numbers of building is the only concerned factor. For example, with the reduction of the number of storey of building, the requirement of external wall k-value will be increased. Considering such differences, a typical building with identical parameters is supposed to put everything on the same level in the comparison. We assumed a 10-storey building with a shape coefficient of 0.25 , a window-wall ratio of 0.3 in all directions. The windows are all double-glassed with a single metal frame.

ASHRAE 90.1-2010 is referred to as a representative of USA standards. According to its climate classification method, Beijing belongs to the Climate Zone $4 \mathrm{C}$ with a heat degree-day between 2000 and 3000. Besides, we suppose that the roof insulation is entirely above deck, the walls are massive, the vertical glazing satisfied the requirement for metal framing windows in curtain wall, and the opaque doors are swinging. The corresponding building envelope requirement is listed in the last column of Table 2.

Table 2. Building envelope requirement for residential in Beijing in different standards

\begin{tabular}{|c|c|c|c|c|}
\hline \multirow{2}{*}{ Elements } & \multicolumn{4}{|c|}{ Heat transfer coefficient $\left.\left(\mathbf{W} / \mathbf{m}^{\mathbf{2}} \bullet \mathbf{K}\right)\right)$} \\
\cline { 2 - 5 } & $\begin{array}{c}\text { JGJ } \\
\mathbf{2 6 - 8 6}\end{array}$ & $\begin{array}{c}\text { JGJ } \\
\mathbf{2 6 - 9 5}\end{array}$ & $\begin{array}{c}\text { JGJ 26- } \\
\mathbf{2 0 1 0}\end{array}$ & $\begin{array}{c}\mathbf{A S H R A E} \\
\mathbf{9 0 . 1 - 2 0 1 0}\end{array}$ \\
\hline Roofs & 0.91 & 0.80 & 0.45 & 0.273 \\
\hline External Walls & 1.28 & 1.16 & 0.70 & 0.513 \\
\hline $\begin{array}{c}\text { Core board of } \\
\text { lower balcony } \\
\text { door }\end{array}$ & 1.72 & 1.70 & 1.70 & $\backslash$ \\
\hline $\begin{array}{c}\text { Peripheral } \\
\text { Ground }\end{array}$ & 0.52 & 0.52 & $\backslash$ & $\backslash$ \\
\hline $\begin{array}{c}\text { Non-peripheral } \\
\text { Ground }\end{array}$ & 0.30 & 0.30 & $\backslash$ & $\backslash$ \\
\hline $\begin{array}{c}\text { Partition walls } \\
\text { of non-heat } \\
\text { room }\end{array}$ & 1.83 & 1.83 & 1.50 & 0.513 \\
\hline $\begin{array}{c}\text { Doors of non- } \\
\text { heat room }\end{array}$ & 2.91 & 2.00 & 2.00 & 3.975 \\
\hline
\end{tabular}




\begin{tabular}{|c|c|c|c|c|}
\hline $\begin{array}{c}\text { Outdoor air } \\
\text { contact floor- } \\
\text { slabs }\end{array}$ & $\backslash$ & 0.50 & 0.60 & 0.420 \\
\hline $\begin{array}{c}\text { Roofs of non- } \\
\text { heat basement }\end{array}$ & $\backslash$ & 0.55 & 0.65 & 0.420 \\
\hline $\begin{array}{c}\text { External } \\
\text { windows }\end{array}$ & 6.40 & 4.00 & 2.80 & 2.84 \\
\hline
\end{tabular}

In general, the requirement of envelope is raised. The ground insulation is no longer required in JGJ 26-2010 and ASHRAE standard because this is not that significant for a high-rise building. Besides, it is found that the requirement of outdoor air contact floor and roofs of non-

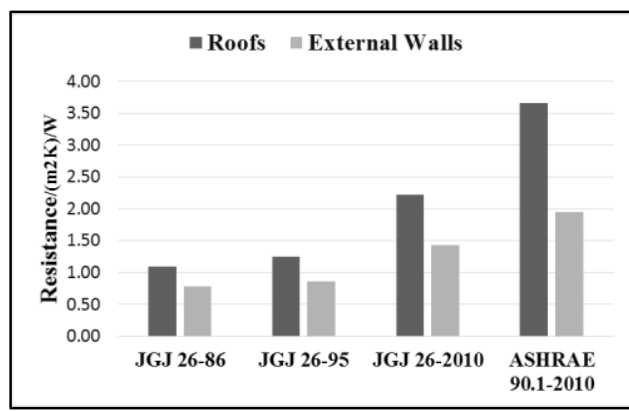

heat basement is lower in JGJ 26-2010 than former standards. In fact, the JGJ 26-2010 standard divided these two requirements by layer number while the former standards regulate all buildings with the same value, corresponding requirements for a low-rise building in JGJ 26-2010 is higher than the former ones. This can also be seen as an advantage of the new standard.

Thermal resistance of roofs, external walls and windows indicates the insulation performance of a building. Fig.1 shows the varied levels of such performance among the standards. Table 3 gives out detailed value and ratio of resistances in the specific Chinese standards to resistances in the US standards.

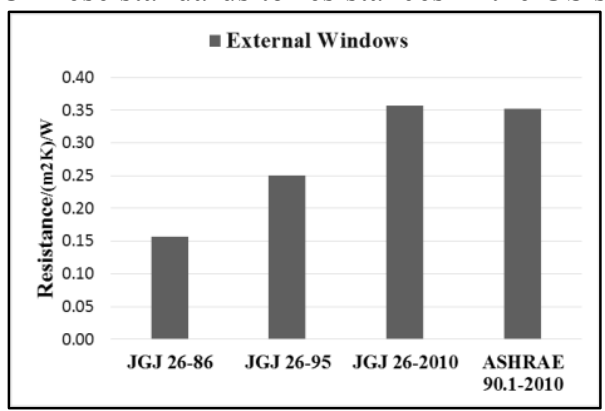

Fig. 1. Minimum thermal resistance of roofs, external walls (left) and external windows (right) in the 4 standards.

Table 3. Minimum Thermal resistance of external envelopes and relative difference of each standard

\begin{tabular}{|c|c|c|c|c|c|c|c|}
\hline \multirow{2}{*}{ Elements } & \multicolumn{7}{|c|}{ Thermal resistance $\left(\left(\mathbf{m}^{2} \cdot \mathbf{K}\right) / \mathbf{W}\right)$} \\
\hline & $\begin{array}{c}\text { JGJ 26- } \\
86\end{array}$ & $\begin{array}{c}\text { Ratio of } \\
\text { resistances }\end{array}$ & $\begin{array}{c}\text { JGJ 26- } \\
95\end{array}$ & $\begin{array}{c}\text { Ratio of } \\
\text { resistances }\end{array}$ & $\begin{array}{c}\text { JGJ 26- } \\
2010\end{array}$ & $\begin{array}{l}\text { Ratio of } \\
\text { resistances }\end{array}$ & $\begin{array}{c}\text { ASHRAE 90.1- } \\
2010\end{array}$ \\
\hline Roofs & 1.099 & $30.0 \%$ & 1.250 & $34.1 \%$ & 2.222 & $60.7 \%$ & 3.663 \\
\hline $\begin{array}{c}\text { External } \\
\text { Walls }\end{array}$ & 0.781 & $40.1 \%$ & 0.862 & $44.2 \%$ & 1.429 & $73.3 \%$ & 1.949 \\
\hline $\begin{array}{l}\text { External } \\
\text { Windows }\end{array}$ & 0.156 & $44.4 \%$ & 0.250 & $71.0 \%$ & 0.357 & $101.4 \%$ & 0.352 \\
\hline
\end{tabular}

a. Ratio of resistances in the specific Chinese standard to resistances in the US standard

Table 4. Minimum design efficiency for coal-fired boiler required by 3 Chinese standards

\begin{tabular}{|c|c|c|c|}
\hline \multirow{2}{*}{ Boiler capacity(MW) } & \multicolumn{3}{|c|}{ Coal-fired boiler efficiency (\%) } \\
\cline { 2 - 4 } & JGJ 26-86 & JGJ 26-95 & JGJ 26-2010 \\
\hline 0.7 & 62 & $\backslash$ & $\backslash$ \\
\hline 1.4 & 70 & $\backslash$ & $\backslash 3$ \\
\hline 2.8 & 72 & 72 & 74 \\
\hline 4.2 & 72 & 73 & 78 \\
\hline 7.0 & 74 & 74 & 79 \\
\hline 14.0 & $\backslash$ & 76 & 80 \\
\hline$>28.0$ & $\backslash$ & 78 & \\
\hline
\end{tabular}

Table 5. Minimum design efficiency for oil-fired boiler required by JGJ 26-2010 and ASHRAE 90.1-2010

\begin{tabular}{|c|c|c|}
\hline \multirow{2}{*}{ Boiler capacity(MW) } & \multicolumn{2}{|c|}{ Oil-fired boiler efficiency (\%) } \\
\cline { 2 - 3 } & JGJ 26-2010 & ASHRAE 90.1-2010 \\
\hline 0.7 & 86 & 78 \\
\hline 1.4 & 87 & 83 \\
\hline 2.8 & 87 & \multirow{2}{|}{} \\
\hline
\end{tabular}




\begin{tabular}{|c|c|}
\hline 4.2 & 88 \\
\hline 7.0 & 89 \\
\hline 14.0 & 90 \\
\hline$>28.0$ & 90 \\
\hline
\end{tabular}

The comparison between 3 Chinese standards show a consistent development over the last 20 years, but in performance of roofs and external walls, the requirement is still lower than the contemporaneous USA standard. The requirement of external window of last 2 standards is almost the same.

\subsection{HVAC Systems}

In cold areas, buildings are heat dominated, so we choose the key performance index of heat system to represent the requirement level for HVAC systems in each standard. The coal-fired boiler is the traditional heating mode of cold areas, whose efficiency indicate the transmission rate of energy and is regulated by the standard. Therefore, the minimum design efficiency of coal-fired boiler required in standards is compared. The coal type is set to bituminous coal II. Different capacity of boiler are listed in Table 4.

In ASHRAE standard, there are only requirements for gas- and oil-fired boilers, which is not included in the JGJ 26-86 and JGJ 26-95, so we compare it with JGJ 262010 in Table 5.

\section{Conclusion}

China's residential buildings energy efficiency standardization work started from the 1980s and has developed for 30 years. In this paper, the 3 editions of standards used before are reviewed and key indices are compared. The conclusions are as follows:

1) The first energy efficiency standard of China was proposed in 1986 and went through a rapid development since then. After several revisions, the energy consumption reduction percentage has raised from $30 \%$ of first JGJ $26-86$ to $65 \%$ of the JGJ 26-2010. The insulation performance of roofs and external walls increased respectively by $103 \%$ and $83 \%$, and the window performance increased by $130 \%$.

2) The building energy efficiency standardization work started late in our country. The gap of energy efficiency requirement in standards between china and the USA still exist and it is gradually narrowing. When it comes to the requirement for external window and oil-fired boiler efficiency, the domestic standard is even higher.

3) The urban-rural residential construction outline in $13^{\text {th }}$ five-year plan has proposed that, by 2020 , the newlydeveloped building energy efficiency requirement of implemented standard should increase by $20 \%$ compared to the end of $12^{\text {th }}$ five-year period [7]. To fulfill the goal, JGJ 26 "Design standard for energy efficiency of residential buildings in severe cold and cold zones" is under a new round of revision, the expected energy saving ratio is $75 \%$. Besides, guideline of ultra-low energy consumption residential building and technical criteria of nearly zero energy building are both under formulation. In this way, we keep a consistent rise of the mandatory standards for building energy efficiency design, establish technical criteria with higher energy saving performance for guideline and finally fulfill the total amount control of building energy consumption.

\section{Acknowledgements}

This work was funded by the Research on the Definition and Technical Criteria of Nearly Zero Energy Building program under number 2017YFC0702600, which is one of the Chinese

National Program on Key Basic Research Project.

\section{References}

1. S. Nadel, The Future of standards, ENERG BUILDINGS 26(1997):119-128.

2. PRC Urban and Rural Construction Environmental Protection Department, Civil building energy efficiency design standards (residential building heating part), (1986).

3. PRC Construction Department, Energy conservation design standard for new heating residential buildings, (1996).

4. S. Lang, Compiling thinking and progress of energy efficiency design standards in buildings in China, HV\&AC, 34(2004):30-36.

5. PRC Housing and Urban-rural Development Department, Design standard for energy efficiency of residential buildings in severe cold and cold zones, (China Building Industry Press, 2010)

6. American Society of Heating, Refrigerating and Airconditioning Engineers, ANSI/ASHRAE/IES Standard 90.1-2010. Energy standard for buildings except low-rise residential buildings. (Atlanta: ASHRAE, 2010)

7. PRC Housing and Urban-rural Development Department, $13^{\text {th }}$ five-year plan for building energy conservation and development of green buildings, (2017) 